\title{
Quantification of Yield Losses Caused by Barley yellow dwarf virus in Wheat and Oats
}

\author{
S. J. McKirdy and R. A. C. Jones, Plant Pathology Section, Department of Agriculture, Locked Bag No. 4, Bent- \\ ley, W. A. 6983, Australia; and F. W. Nutter, Jr., Department of Plant Pathology, 351 Bessey Hall, Iowa State Uni- \\ versity, Ames 50011
}

\begin{abstract}
McKirdy, S. J., Jones, R. A. C., and Nutter, F. W., Jr. 2002. Quantification of yield losses caused by Barley yellow dwarf virus in wheat and oats. Plant Dis. 86:769-773.

Grain yield data obtained from five field experiments in Western Australia from 1992 to 1994, in which insecticide applications suppressed the spread of Barley yellow dwarf virus (BYDV) in wheat and oats, were used to quantify the relationships between incidence of BYDV and yield gaps, 500-seed weight, and percent shriveled grain. Yield gaps ranged from 0 to $2,700 \mathrm{~kg} / \mathrm{ha}$, and the relationship between yield gap and incidence of BYDV was always linear. Single point yield loss models revealed that BYDV infection explained most of the variation in yield gaps. There was a significant linear relationship between incidence of BYDV and 500-seed weight for wheat, but not for oats. The percent shriveled grain always increased with an increase in incidence of BYDV in wheat but not in oats. Cost-benefit relationships were determined for the return on investment when deploying imidacloprid-treated seed and/or one or two foliar applications of pyrethroid insecticides to reduce incidence of BYDV and to decrease the yield gaps in wheat and oats due to BYDV.
\end{abstract}

Additional keywords: Avena sativa, plant disease losses, plant virus epidemiology, Triticum aestivum

Barley yellow dwarf virus (BYDV) is a phloem-limited virus transmitted by aphids in a circulative, nonpropagative manner $(16,27)$. BYDV causes the most prevalent and economically important virus disease of cereals worldwide $(1-4,13,15,16,20,21$, 27,28,36,38,39). Annual and perennial grasses and volunteer cereals play an important role in the epidemiology of BYDV, because they serve as reservoirs of inoculum for virus acquisition by aphids and subsequent transmission to cultivated cereal crops $(1,7,8,18,24-26)$. In southwestern Australia, cereal crops are sown following rains in late April or May (late autumn) and harvested in December. Rhopalosiphum padi (oat aphid) and $R$. maidis (corn aphid) are the most abundant aphid species colonizing cereals, but $R$. insertum, $R$. rufiabdominalis, and Sitobion miscanthi are also found in southwestern Australia $(18,22,24,25)$. The most severe epidemics of BYDV and resulting crop damage occur when viruliferous aphids move from

Corresponding author: Forrest W. Nutter, Jr. E-mail: fwn@iastate.edu

Journal Paper No. J-19456 of the Iowa Agriculture and Home Economics Experiment Station, Ames, IA. Project No. 3394.

Accepted for publication 1 March 2002.

Publication no. D-2002-0425-01R

(C) 2002 The American Phytopathological Society grasses to cereal crops soon after seedlings have emerged $(12,18,24,25,39)$.

Host resistance $(14,26,27)$ and insecticide applications $(12,21,23-25)$ are used to control BYDV in commercial cereal crops and in other virus pathosystems (37). For example, in southwestern Australia, two sprays of pyrethroid insecticide is a common practice for control of BYDV $(23,24)$.

Banks et al. (1) regressed incidence of BYDV against the grain yields (tons/ha) of six winter wheat genotypes based on incidence assessments made 32 weeks after sowing. There was a negative linear relationship between incidence of BYDV and wheat yield, but the damage coefficients (slopes) and the standard errors of the estimate of $y$ (SEEy) for those equations were not reported. Perry et al. (36) found that incidence of BYDV-infected plants in three soft winter wheat cultivars was associated with a decrease in grain yields. Wheat yields decreased by 27 to $45 \mathrm{~kg} / \mathrm{ha}$ for each $1 \%$ increase in incidence of BYDV. However, the impacts of incidence of BYDV on components of yield were not investigated. Other than these two studies, no other quantitative information has been published concerning the impact of increasing incidence of BYDV on the yield of cereals and their yield components (27). To date, there is no quantitative information available concerning the relationship between incidence of BYDV and the yield losses in oats. Moreover, no information is available on the effects of incidence of
BYDV on specific yield components of wheat and oats or on the effect of incidence of BYDV on the percentage of shriveled grain.

Although the incidence of BYDV in field experiments in southwestern Australia was shown to be greatly suppressed using insecticides $(24,25)$, the relationships between incidence of BYDV and grain yield, 500 -seed weight, and the percentage of shriveled grain in wheat and oats were not quantified in these reports $(24,25)$. Therefore, this study used their data to (i) quantify the relationships between incidence of BYDV and yield of wheat and oats in southwestern Australia, and (ii) quantify the impact of incidence of BYDV on 500seed weight and percent shriveled grain of wheat and oats in southwestern Australia.

\section{MATERIALS AND METHODS}

Field experiments. Field experiments were conducted to measure the impact of insecticide applications and time of sowing on BYDV development of BYDV epidemics and grain yield of wheat and oats $(24,25)$. A total of five experiments, three on wheat (cv. Spear in 1992, 1993, and 1994) and two on oats (cv. Dalyup in 1993 and 1994), were conducted at two locations in Western Australia, Manjimup and Mt. Barker. Plots were arranged in a randomized complete block design, and the number of replications within each experiment ranged from four to eight. Seed was sown with a cone seeder at $80 \mathrm{~kg} / \mathrm{ha}$. All foliarapplied insecticides were applied to the crop at 100 liters/ha using a boom sprayer. Overall plot sizes for each experimental unit ranged from $2.8 \times 15 \mathrm{~m}$ to $4.2 \times 25 \mathrm{~m}$. All experiments were sown between 12 and 25 May (24,25). Specific details concerning plot insecticide treatments are provided in the original publications $(24,25)$.

To measure grain yields, each plot was harvested after discarding $0.5 \mathrm{~m}$ around the plot edges to minimize border effects. Seed weight was measured by weighing a subsample of 500 seeds from each plot. Percent shriveled grain was measured by passing a subsample of $10 \mathrm{~g}$ of seeds per plot over a 2-mm slotted sieve. The weight of seeds with a width less than $2 \mathrm{~mm}$ that passed through the sieve was recorded and the percentage of shriveled grain was calculated $(24,25)$.

Assessment of incidence of BYDV. The top $10 \mathrm{~cm}$ of the newest, fully expanded 
leaf from 15 to 50 plants were arbitrarily selected from each plot at regularly spaced intervals (two to five times) during the growing season $(24,25)$. Samples were tested for BYDV by enzyme-linked immunosorbent assay (ELISA) (5) as described by McKirdy and Jones $(24,25)$. Antiserum to BYDV serotype PAV was used for each sampling date. In addition, samples taken at the final sampling date were also tested with antisera to serotype MAV and cereal yellow dwarf virus serotypes RPV and RMV. Percent incidence of BYDV was estimated from grouped sample test results using the formula of Gibbs and Gower (10).

Single point yield gap models. Assessments of the incidence of BYDV for each sampling date were related to the yield gap that was measured for each treatment within each experimental location and year using linear regression (29,31). Yield gaps (33) were measured for each treatment by determining the maximum attainable yield (33) achieved for each location and year (highest-yielding treatment) and subtracting the yield obtained from each treatment within that experiment (i.e., the site-specific attainable yield of each experiment minus the actual harvested yield of each treatment) (33). Yield gaps $(y)$ were then used as the dependent variable, and corresponding incidence of BYDV for each treatment was used as the independent variable to construct single point regression models for each sampling date, location, and year.

Statistical analysis. Linear regression analysis $(19,31)$ was used to quantify the relationships between incidence of BYDV $(x)$ with yield gaps, seed weight, and percent shriveled grain $(y)$. Coefficients of determinations $\left(R^{2}\right), F$ tests, and standard errors of the $Y$ estimate (SEEy) were calculated using the Statistical Analysis System (version 6.12, SAS Institute, Cary, NC) and used to determine the goodness-of-fit of each single point regression model $(19,31,32)$. Slopes and intercepts within and among experiments were compared using $t$ tests $(19,35)$.

\section{RESULTS}

Yield gaps (losses) due to BYDV in wheat and oats were substantial and ranged from 1,300 to $2,700 \mathrm{~kg} / \mathrm{ha}$ among the five experiments (Fig. 1A and B). The relationship between yield gaps and incidence of BYDV was linear for all five experiments. BYDV assessments performed at or closest to the time of flag leaf emergence gave the best relationship to wheat and oat yields (Table 1). Single point yield loss models based on incidence of BYDV at the time of flag leaf emergence were significant $(P \leq$ 0.05 ) and explained 48 to $80 \%$ of the variation in wheat yield gaps (Fig. 1A) and 73 to $85 \%$ of the variation in oat yield gaps (Fig. 1B). Damage functions (slopes) relating incidence of BYDV to wheat yield gaps ranged from 13 to $25 \mathrm{~kg} / \mathrm{ha}$ for each $1 \%$ increase in incidence of BYDV in wheat and 44 to $55 \mathrm{~kg} / \mathrm{ha}$ for each $1 \%$ increase in incidence of BYDV in oats.

Assessments for incidence of BYDV at flag leaf emergence showed a strong linear relationship (highly significant $F$ tests) with 500-seed weight of wheat (Fig. 1C). For wheat, damage coefficients (slopes) indicated that 500 -seed weight decreased by 0.04 to $0.082 \mathrm{~g}$ for each $1 \%$ increase in incidence of BYDV (Fig. 1C). Coefficients of determination for the wheat models ranged from 47 to $86 \%$, indicating that incidence of BYDV at flag leaf emergence explained 47 to $86 \%$ of the variation in 500 -seed weight. Standard errors of the $y$ estimate for these models were 1.16, 0.54, and 1.30 for the 1992 experiment at Manjimup, the 1993 experiment at Manjimup, and the 1993 experiment at Mt. Barker, respectively. The $F$ statistics relating incidence of BYDV to 500-seed weight in oats were not significant, indicating there was not a linear relationship between incidence of BYDV and seed weight in these two oat experiments (Fig. 1D).

For each $1 \%$ increase in incidence of BYDV at the time of flag leaf emergence, the percentage of shriveled wheat grain increased by 0.05 to $0.3 \%$ (Fig. 1E). Coefficients of determination for these models ranged from 25 (Mt. Barker in 1993) to 92\% (Manjimup in 1992), with standard errors of the estimate for $y$ ranging from 0.8 to $3.2 \%$. For oats, percentage of shriveled grain increased with respect to incidence of BYDV $\left(R^{2}=25.6 \%\right.$, SEE $y=$ 1.05) in one experiment (Manjimup in 1993), but decreased $(-0.53)$ for each $1 \%$ increase in incidence of BYDV $\left(R^{2}=49.7\right.$, SEEy $=4.66)$ in the second oat experiment (Manjimup in 1994) (Fig. 1F).

\section{DISCUSSION}

Among the different field experiments, the differences in grain yield between the best treatment (attainable yield) and the nonsprayed control treatment ranged from 1,300 to $2,100 \mathrm{~kg} / \mathrm{ha}$ for wheat and from 1,700 to $2,700 \mathrm{~kg} / \mathrm{ha}$ for oats. Quantifying and reporting crop damage in terms of the yield gaps (33) caused by epidemics of BYDV in actual units of yield, as opposed to reporting percent yield loss, provides a more sound mathematical basis to determine the benefits versus costs of deploying disease management tactics, such as the use of seed- and foliar-applied insecticides, to minimize crop losses. When percent yield loss data are used, the ability to multiply damage functions (slopes relating disease incidence to units of yield in $\mathrm{kg} / \mathrm{ha}$ ) by present or expected future crop price functions ( $\$$ per $\mathrm{kg}$ ) is lost $(30,41)$. Multiplying the damage functions reported in our study by the present or expected prices for wheat and oats allows plant pathologists and agricultural economists to easily develop cost-benefit analyses for various disease management scenarios and tactics $(30,33,34)$. For example, assuming the price of wheat is $A \$ 217 / t$, this would represent direct losses in our study ranging from $\mathrm{A} \$ 282$ to $\mathrm{A} \$ 455$ per ha for wheat. Other price functions (higher or lower) can be used to calculate the predicted loss in A \$ per ha (or any other currency). The cost of insecticide applications would be approximately A $\$ 102$ per ha for seed dressing with imidacloprid, $A \$ 23$ per ha for two foliar applications of alpha-cypermethrin, and $\mathrm{A} \$ 125$ for both tactics. Assuming the attainable yield for each site is $4 \mathrm{t} / \mathrm{ha}$ and based on our damage functions relating incidence of BYDV to yield gaps, each $1 \%$ increase in incidence of BYDV resulted in an average decrease (slopes averaged over the three models) of $18 \mathrm{~kg} / \mathrm{ha}$ in the yield gap for wheat (i.e., yield increases by 18 $\mathrm{kg} / \mathrm{ha}$ for each $1 \%$ decline in the incidence of BYDV). Production managers, economists, extension plant pathologists, etc., can assume different chemical and crop prices and yield potentials to calculate cost-benefit ratios for different management scenarios. Using the crop and insecticide prices quoted above and assuming that (i) incidence of BYDV at the time of flag leaf emergence is $60 \%$ (as Fig. 1A for example), (ii) seed treatment decreases incidence of BYDV by $10 \%(24,25)$, (iii) two applications of alpha-cypermethrin decrease incidence by $40 \%(24,25)$, and (iv) use of seed and foliar-applied insecticides together would decrease incidence by $55 \%(24,25)$, the use of these insecticide tactics would likely result in a net return on investment of $-\mathrm{A} \$ 63 / \mathrm{ha}$ for seed treatment alone, A $\$ 133 /$ ha for two applications of alpha-cypermethrin, and A $\$ 90 /$ ha when both seed treatment and applications of alpha-cypermethrin are utilized. If the same analysis is used for oats (assuming an attainable yield of $6 \mathrm{t} / \mathrm{ha}$ ), then each $1 \%$ increase in incidence of BYDV would result in an average increase of $49 \mathrm{~kg} / \mathrm{ha}$ in the yield gap for oats. Based upon an oat price of $\mathrm{A} \$ 140 / \mathrm{t}$, the net return on investment would be $-\mathrm{A} \$ 16 /$ ha for use of insecticide seed treatment alone, A $\$ 268 /$ ha for two applications of alpha-cypermethrin, and $\mathrm{A} \$ 269 /$ ha for both seed treatment and two applications of alpha-cypermethrin (33).

Infection of cereals with BYDV can diminish the number of plants per row, the number of tillers per plant, the number of florets or seeds per head (tiller), and seed weight $(4,16,17)$. Although incidence of BYDV explained a significant proportion of the variation in 500-seed weight of wheat $\left(R^{2}=47\right.$ to $\left.82 \%\right)$, BYDV may also have adversely affected the number of tillers per plant and the number of seeds per head (the number of florets per head). Fitzgerald and Stoner (9) found that infection of hard red winter wheat with BYDV diminished the number of heads per $30 \mathrm{~cm}$ of row, and that infection with BYDV 
resulted in fewer seeds per head as well as diminished seed weight. Jensen et al. (17) found that infection of wheat by BYDV also adversely affected the number of flo- rets per head. Hoffman and Kolb (15) reported that BYDV infection of winter wheat greatly reduced the number of seeds per head, and to a lesser extent, seed weight in BYDV-infected plots compared with insecticide-treated control plots, but tiller number per row was not affected. Rather than inoculating whole plots at one
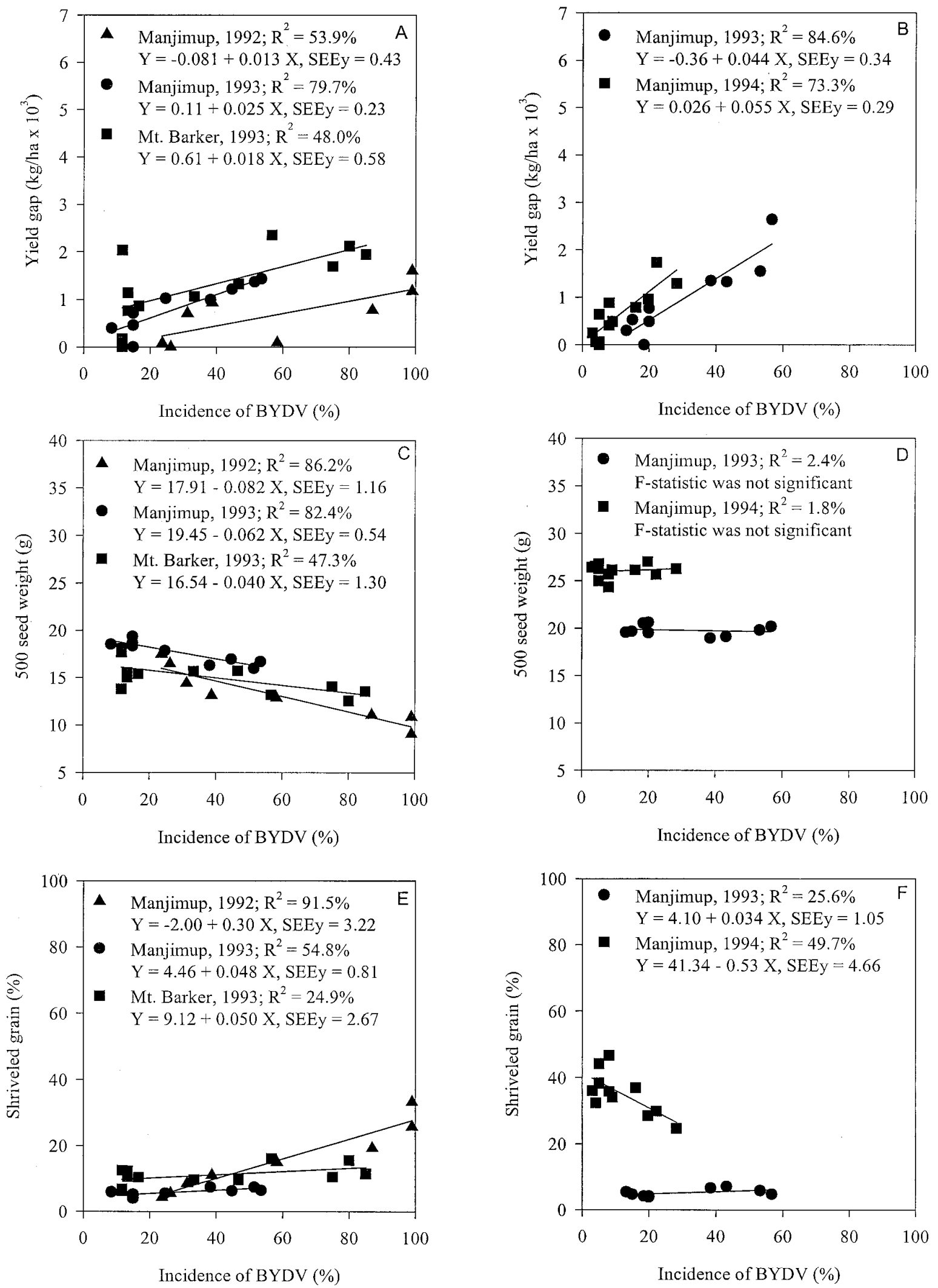

Fig. 1. Relationship between incidence of Barley yellow dwarf virus (BYDV) and A, yield gap, C, 500-seed weight, and E, percent shriveled grain in three field experiments with wheat; and B, yield gap, D, 500-seed weight, and F, percent shriveled grain in two field experiments with oats in southwestern Australia in 1992, 1993, and 1994. Linear regression analyses were used to calculate parameters and statistics. 
or two points in time (which limits yield compensation), we also found that 500seed weight decreased in response to increasing incidence of BYDV in wheat when using insecticides to slow down disease development. Conversely, 500-seed weight in oats was not adversely affected by an increase in incidence of BYDV (up to $60 \%$ ), indicating that the number of heads per row and/or the number of seeds per head were more adversely affected in oats than in wheat. The impact of BYDV infection on the yield components of oats and wheat is a function of the time of plant infection $(27,39)$. The growth stage of the crop at the time of infection affects the duration of infection and the capability of individual healthy plants in the population to compensate for the poorer growth of adjacent BYDV-infected plants within the crop $(17,39,40)$. For example, Gildow and Frank (11) found that early-season plant infection (inoculation of whole plots with viruliferous aphids) had a greater effect on the number of oat heads per $m$ of row and the number of oat seeds per head, but there was no significant effect of BYDV on 1,000 -seed weight. Since all plants in the oat plots were inoculated with viruliferous aphids 4 weeks or 6 weeks after oat emergence, there was little opportunity for plants to compensate due to synchronous infection with viruliferous aphids. In contrast, the proportion of aphids that were viruliferous versus nonviruliferous in our study differed among years and locations. Therefore, individual plants in the host population were infected at different growth stages, as would occur in natural BYDV epidemics in commercial crops. As a result of the more natural disease development that occurred in our study, the incidence of BYDV in oats ranged from $0 \%$ to approximately $60 \%$ for disease final ratings in 1993, and from 0 to $30 \%$ in 1994 , and there was a greater opportunity for healthy plants to compensate for diseased plants by producing more seeds per head, and/or by increasing seed weight, than might occur when all oat plants are inoculated at the same time.

The coefficient of determination $\left(R^{2}\right)$ is one of the most widely used statistics to assess the goodness-of-fit of both empirical and mechanistic models fitted to data (19). Cornell and Berger (6) pointed out that the coefficient of determination is influenced by several factors, some of which are associated with the range and distribution of the independent variable (i.e., incidence of BYDV in the present study). Bauske et al. (2) published a multi-season critical point model relating incidence of BYDV to the percentage of maximum yield obtained for two oat cultivars in 1991 and 1992. However, this study was not designed to achieve a diverse range in the incidence of BYDV within seasons, which resulted in an erratic range and distribution in the incidence of BYDV among combined seasons. Moreover, incidence values between 48 and $72 \%$ were lacking and, therefore, the shape of the yield loss curve may have fit a nonlinear (negative exponential) model in addition to the linear model proposed by the authors. Because their model related percent yield data to incidence of BYDV, this model is not directly comparable with other BYDV critical point models. Since absolute units of yield, such as $\mathrm{t} / \mathrm{ha}$ or $\mathrm{kg} / \mathrm{ha}$, were not used $(1,9,36)$ when percent yield loss data were reported, the reference points for yield were lost (33). For example, a $30 \%$ loss due to BYDV when the attainable yield (with no BYDV) is $6 \mathrm{t} / \mathrm{ha}$ is quite different from a $30 \%$ loss when the attainable yield is $3 \mathrm{t} / \mathrm{ha}$.

In an attempt to obtain a uniform range in incidence of BYDV for developing a yield loss model, Hoffman and Kolb (15) inoculated wheat plots with viruliferous aphids (R. padi) carrying BYDV serotype PAV at 1to 2-week intervals and examined correlations between the percentage of plants expressing BYDV symptoms and grain yield. Because a high incidence of virus-infected plants resulted from their inoculation method, the disease incidence values in inoculated plots ranged from 55 to $85 \%$ in 1993 and from 17 to $63 \%$ in 1994, and there was little opportunity for yield compensation. Moreover, predictions based on incidence of BYDV levels above or below these ranges would be extrapolating beyond the scope of the models. Their models were also based on a rather narrow range of incidence of BYDV levels (and an erratic distribution of $x$ values), which may have influenced the predictive value of the yield loss models $\left(R^{2}\right.$ $=46 \%$ in 1993 and was nonsignificant in 1994) (6). In the data used for model development in our study, the range in the number and timing of insecticide applications achieved incidence of BYDV (at the time of flag leaf emergence) that ranged from 0 to $90 \%$ in wheat and from 0 to $60 \%$ in oats.

\section{ACKNOWLEDGMENTS}

The Australian Grains Research and Development Corporation provided financial support for

Table 1. Relationship between incidence of Barley yellow dwarf virus (BYDV) and the yield gap ${ }^{\mathrm{a}}$ (kg/ha) as affected by time of assessment for BYDV in wheat and oat field trials in southwestern Australia in 1992, 1993, and 1994

\begin{tabular}{|c|c|c|c|c|c|c|c|}
\hline Host & Location & Year & Days after planting & $R^{2}(\%)^{\mathrm{c}}$ & Intercept $^{d}$ & Slope $e^{e}$ & SEEy $y^{\mathrm{f}}$ \\
\hline \multirow[t]{5}{*}{ Wheat } & Manjimup & 1992 & 68 & 49.6 & 0.33 & 0.077 & 0.45 \\
\hline & & & 88 & 61.7 & 0.095 & 0.047 & 0.39 \\
\hline & & & 103 & 43.7 & 0.0080 & 0.014 & 0.47 \\
\hline & & & $117(\mathrm{FL})^{\mathrm{g}}$ & 53.9 & -0.081 & 0.013 & 0.43 \\
\hline & & & 132 & 31.6 & -0.52 & 0.015 & 0.52 \\
\hline \multirow[t]{4}{*}{ Wheat } & Manjimup & 1993 & 56 & 57.0 & 0.32 & 0.098 & 0.34 \\
\hline & & & 90 & 37.3 & -0.077 & 0.032 & 0.41 \\
\hline & & & 104 (FL) & 79.7 & 0.11 & 0.025 & 0.23 \\
\hline & & & 118 & 66.0 & 0.12 & 0.018 & 0.30 \\
\hline \multirow[t]{2}{*}{ Wheat } & Mt. Barker & 1993 & 99 & 9.4 & 1.07 & 0.020 & 0.76 \\
\hline & & & $135(\mathrm{FL})$ & 48.0 & 0.61 & 0.018 & 0.58 \\
\hline \multirow[t]{4}{*}{ Oat } & Manjimup & 1993 & 56 & 35.4 & -0.72 & 0.026 & 0.70 \\
\hline & & & 90 & 85.8 & -0.86 & 0.060 & 0.33 \\
\hline & & & 104 (FL) & 84.6 & -0.36 & 0.044 & 0.34 \\
\hline & & & 118 & 65.3 & -1.29 & 0.040 & 0.51 \\
\hline \multirow[t]{4}{*}{ Oat } & Manjimup & 1994 & 87 & 34.5 & 0.38 & 0.260 & 0.45 \\
\hline & & & 120 & 51.4 & -0.16 & 0.150 & 0.39 \\
\hline & & & 133 (FL) & 73.3 & 0.026 & 0.055 & 0.29 \\
\hline & & & 145 & 75.6 & -0.0097 & 0.026 & 0.28 \\
\hline
\end{tabular}

a Yield gaps were calculated as the highest treatment yield obtained for a specific experiment (location and year) minus the yield obtained for each treatment in the same experiment.

b All $F$ statistics for these models were significant $(P \leq 0.05)$.

${ }^{\mathrm{c}} R^{2}$ is the coefficient of determination. This statistic gives the amount of variation in $y$ (yield gap) that is explained by $x$ (incidence of BYDV).

${ }^{d}$ All $Y$ intercepts for each regression model relating the yield gap $(y)$ to incidence of BYDV $(x)$ were significant $(P \leq 0.05)$.

${ }^{\mathrm{e}}$ All slopes for regression models relating the yield gap $(y)$ to incidence of BYDV $(x)$ were significant $(P \leq 0.05)$.

${ }^{\mathrm{f}}$ Standard error of the estimate for a predicted $Y$.

$\mathrm{g}$ FL indicates assessments closest to the time of flag leaf emergence. 
the field experiments and for the third author during sabbatical leave in Australia.

\section{LITERATURE CITED}

1. Banks, P. M., Davidson, J. L., Bariana, H., and Larkin, P. J. 1995. Effects of barley yellow dwarf virus on the yield of winter wheat. Aust. J. Agric. Res. 46:935-946.

2. Bauske, E. M., Bissonnette, S. M., and Hewings, A. D. 1997. Yield loss assessment of barley yellow dwarf disease on spring oats in Illinois. Plant Dis. 81:485-488.

3. Bayoumi, O. C., and Kummert, J. 1986. Effect of systemic carbamate insecticides on virus yield and symptom expression of BMVor BYV-infected sugar beet plants. Med. Fac. Landbouww. Rijksuniv. 51:845-853.

4. Bos, L. 1982. Crop losses caused by viruses. Crop Prot. 1:263-282.

5. Clark, M. F., and Adams, A. N. 1977. Characteristics of the microplate method of enzymelinked immunosorbent assay for the detection of plant viruses. J. Gen. Virol. 34:475-483.

6. Cornell, J. A., and Berger, R. D. 1987. Factors that influence the value of the coefficient of determination in simple linear and nonlinear regression models. Phytopathology 77:63-70.

7. Dempster, L. C., and Holmes, S. J. I. 1995. The incidence of strains of barley yellow dwarf virus in perennial ryegrass crops in south-west and central Scotland. Plant Pathol. 44:710-717.

8. El Yamani, M., and Hill, J. H. 1992. Characterization, grass hosts, and epidemiology of barley yellow dwarf virus isolates in WestCentral Morocco. Phytopathol. Mediterr. 31:1163-1169.

9. Fitzgerald, P. J., and Stoner, W. N. 1967. Barley yellow dwarf studies in wheat (Triticum aestivum L.) I. Yield and quality of hard red winter wheat infected with barley yellow dwarf virus. Crop Sci. 7:337-341.

10. Gibbs, A. J., and Gower, J. C. 1960. The use of a multiple transfer method in plant virus transmission studies - Some statistical points arising in the analysis of results. Ann. Appl. Biol. 48:75-83

11. Gildow, F. E., and Frank, J. A. 1988. Barley yellow dwarf virus in Pennsylvania: Effect of the PAV isolate on yield components of Nobel spring oats. Plant Dis. 72:254-256.

12. Gourmet, C., Hewings, A. D., Kolb, F. L., and Smyth, C. A. 1994. Effect of imidacloprid on nonflight movement of Rhopalosiphum padi and the subsequent spread of barley yellow dwarf virus. Plant Dis. 78:1098-1101.

13. Gray, S. M., Chapin, J. W., Smith, D. M., Banerjee, N., and Thomas, J. S. 1998. Barley yellow dwarf luteoviruses and their predominant aphid vectors in winter wheat grown in South Carolina. Plant Dis. 82:1328-1333.
14. Gray, S. M., Smith, D., and Sorrells, M. 1994. Reduction of disease incidence in small field plots by isolate-specific resistance to barley yellow dwarf virus. Phytopathology 84:713718 .

15. Hoffman, T. K., and Kolb, F. L. 1998. Effects of barley yellow dwarf virus on yield and yield components of drilled winter wheat. Plant Dis. 82:620-624.

16. Jensen, S. G., and D'Arcy, C. J. 1995. Effects of barley yellow dwarf on host plants. Pages 55-74 in: Barley Yellow Dwarf: 40 Years of Progress. C. J. D'Arcy and P. A. Burnett, eds. American Phytopathological Society, St. Paul, $\mathrm{MN}$.

17. Jensen, S. G., Fitzgerald, P. J., and Thysell, J. R. 1971. Physiology and field performance of wheat infected with barley yellow dwarf virus. Crop Sci. 11:775-780.

18. Jones, R. A. C., McKirdy, S. J., and Shivas, R. G. 1990. Occurrence of barley yellow dwarf viruses in over-summering grasses and cereal crops in Western Australia. Aust. Plant Pathol. 19:90-96.

19. Kleinbaum, D. G., and Kupper, L. L. 1978. Applied Regression Analysis and Other Multivariate Methods. Duxbury Press, North Scituate, MA.

20. Knight, J. D., Tatchell, G. M., and Norton, G. A. 1996. A structured workshop approach for problem analysis and solution finding: An example using the problems of barley yellow dwarf virus in the UK. Agric. Sys. 52:113131.

21. McGrath, P. F., and Bale, J. S. 1990. The effects of sowing dates and choice of insecticide on cereal aphids and barley yellow dwarf virus epidemiology in Northern England. Ann. Appl. Biol. 117:31-43.

22. McKirdy, S. J., and Jones, R. A. C. 1993. Occurrence of barley yellow dwarf virus serotypes MAV and RMV in over-summering grasses. Aust. J. Agric. Res. 44:1195-1209.

23. McKirdy, S. J., and Jones, R. A. C. 1995. BYDV spread can be controlled in cereal crops. Farming Ahead 45:48-49.

24. McKirdy, S. J., and Jones, R. A. C. 1996. Use of imidacloprid and newer generation synthetic pyrethroids to control the spread of barley yellow dwarf luteovirus in cereals. Plant Dis. 80:895-901.

25. McKirdy, S. J., and Jones, R. A. C. 1997. Effect of sowing time on barley yellow dwarf virus infection in wheat: Virus incidence and grain yield losses. Aust. J. Agric. Res. 48:199-206.

26. McLean, G. D., Khan, T. N., McLean, R. J., and Portmann, P. A. 1984. Effect of barley yellow dwarf virus infection on two near-isogenic lines of barley. SABRAO J. 16:143-148.

27. Miller, W. A., and Rasochova, L. 1997. Barley yellow dwarf viruses. Annu. Rev. Phytopa- thol. 35:167-190.

28. Moriones, E., Ortego, F., Ruiz-Tapiador, M. Gutierrez, C., Castanera, P., and GarciaArenal, F. 1993. Epidemiology of RPV- and PAV-like barley yellow dwarf viruses on winter barley in central Spain. Crop Prot. 12:224228 .

29. Nutter, F. W., Jr. 1997. Quantifying the temporal dynamics of plant virus epidemics: A review. Crop Prot. 16:603-618.

30. Nutter, F. W., Jr. 2000. Disease losses. Pages 340-351 in: Encyclopedia of Plant Pathology. O. C Maloy and T. D Murray, eds. John Wiley \& Sons, New York.

31. Nutter, F. W., Jr., and Littrell, R. H. 1996. Relationships between defoliation, canopy reflectance and pod yield in the peanut-late leafspot pathosystem. Crop Prot. 15:135-142.

32. Nutter, F. W., Jr., Schultz, P. M., and Hill, J. H. 1998. Quantification of within-field spread of soybean mosaic virus in soybean using strain-specific monoclonal antibodies. Phytopathology 88:895-901.

33. Nutter, F. W., Jr., Teng, P. S., and Royer, M. H. 1993. Terms and concepts for yield, crop loss, and disease thresholds. Plant Dis. 77:211-215.

34. Nutter, F. W., Jr., Teng, P. S., and Shokes, F. M. 1991. Disease assessment terms and concepts. Plant Dis. 75:1187-1188.

35. Padgett, G. B., Nutter, F. W., Jr., Kuhn, C. W and All, J. N. 1990. Quantification of disease resistance that reduces the rate of tobacco etch virus epidemics in bell pepper. Phytopathology 80:451-455.

36. Perry, K. L., Kolb, F. L., Sammons, B., Lawson, C., Cisar, G., and Ohm, H. 2000. Yield effects of barley yellow dwarf virus in soft red winter wheat. Phytopathology 90:1043-1048.

37. Pirone, T. P., Raccah, B., and Madden, L. V. 1988. Suppression of aphid colonization by insecticides: Effect on the incidence of potyviruses in tobacco. Plant Dis. 72:350-353.

38. Sward, R. J., and Lister, R. M. 1987. The incidence of barley yellow dwarf viruses in wheat in Victoria. Aust. J. Agric. Res. 38:821828.

39. Thackray, D., Hawkes, J., and Jones, R. A. C. 2001. Further developments in forecasting aphid and virus risk in cereals. Pages 67-69 in: Western Australian Annual Crop Updates Cereals. R. Jettner and J. Johns, eds. Agriculture Western Australia, Perth, Australia.

40. Waggoner, P. E., and Berger, R. D. 1987. Defoliation, disease, and growth. Phytopathology 77:393-398.

41. Wegulo, S. N., Martinson, C. A., Rivera-C., J. M., and Nutter, F. W., Jr. 1997. Model for economic analysis of fungicide usage in hybrid corn seed production. Plant Dis. 81:415422 . 